Article

\title{
Optimization of Enzyme-Assisted Extraction of Flavonoids from Corn Husks
}

\author{
Antonio Zuorro ${ }^{1, *(\mathbb{D}}$, Roberto Lavecchia ${ }^{1}$, Ángel Darío González-Delgado ${ }^{2}$, \\ Janet Bibiana García-Martinez ${ }^{3}$ and Pasqua L'Abbate ${ }^{4}$ \\ 1 Department of Chemical Engineering, Materials and Environment, Sapienza University, 00184 Rome, Italy; \\ roberto.lavecchia@uniroma1.it \\ 2 Chemical Engineering Department, University of Cartagena, Cartagena 130015, Colombia; \\ agonzalezd1@unicartagena.edu.co \\ 3 Department of Environmental Sciences, Universidad Francisco de Paula Santander, Av. Gran Colombia No. \\ 12E-96, Cúcuta 540003, Colombia; janetbibianagm@ufps.edu.co \\ 4 Department of Civil, Environmental, Building Engineering and Chemistry, Polytechnic University of Bari, \\ 70125 Bari, Italy; pasqua.labbate@poliba.it \\ * Correspondence: antonio.zuorro@uniroma1.it; Tel.: +39-0644585598
}

Received: 1 October 2019; Accepted: 29 October 2019; Published: 3 November 2019

check for updates

\begin{abstract}
Corn husks are an important byproduct of the corn processing industry. Although they are a rich source of bioactive compounds, especially flavonoids, corn husks are usually disposed of or used as animal feed. In this paper, we investigate their recovery by an enzyme-assisted extraction process consisting of a pretreatment of the plant material with cellulase followed by solvent extraction with aqueous ethanol. A four-factor, three-level Box-Behnken design combined with the response surface methodology was used to optimize the enzyme dosage $(0.3-0.5 \mathrm{~g} / 100 \mathrm{~g})$, incubation time $(1.5-2.5 \mathrm{~h})$, liquid-to-solid ratio $\left(30-40 \mathrm{~mL} \mathrm{~g}^{-1}\right)$ and ethanol concentration in the solvent $(60-80 \%$ $v / v)$. Under the optimal conditions, about $1.3 \mathrm{~g}$ of total flavonoids per $100 \mathrm{~g}$ of dry waste were recovered. A statistical analysis of the results was performed to provide a quantitative estimation of the influence of the four factors, alone or in combination, on the extraction yields. Overall, the results from this study indicate that corn husks are a valuable source of flavonoids and that they can be easily recovered by a sustainable and environmentally friendly extraction process.
\end{abstract}

Keywords: flavonoids; corn husks; cellulase; enzyme-assisted extraction; waste valorization

\section{Introduction}

Corn (Zea mays L.) is a member of the family Poaceae and is one of the most abundant crops cultivated worldwide [1]. In addition to being consumed in food products, some parts of corn have gained interest as a source of therapeutic agents [2,3]. For example, corn silk (Stigma maydis), which is made up of the stigmas and styles of the maize plant, has long been used in traditional medicine to treat several diseases and disorders [4]. Its beneficial properties have been attributed to the presence of various bioactive compounds-such as alkaloids, flavonoids, tannins, and vitamins-which are thought to be responsible for its anti-inflammatory, antidiabetic and antitumor activity $[5,6]$.

Corn husks are the thin cellulose-rich leafy sheaths covering the corn cob (Figure 1). They are important byproducts of the corn processing industry and are generated in an amount of about 45 million tons worldwide [7]. As is the case of most agricultural residues, corn husks are usually disposed of or used as animal feed, although several possible ways have been proposed to add value to them. For example, their lignocellulosic nature makes them suitable as a starting material for the production of sugars by chemical or enzymatic hydrolysis [8,9]. Some studies have investigated their 
use as substrate in solid-state fermentation for the production of citric acid [10] or rifamycin B [11]. More recently, it has been shown that cellulose fibers or nanofibers can be easily extracted from corn husks and used as reinforcement in composite materials [12,13]. Corn husks are also a potential source of bioactive compounds, especially anthocyanins and other flavonoids [14,15]. However, only a few papers have been published on their recovery and identifications $[16,17]$.

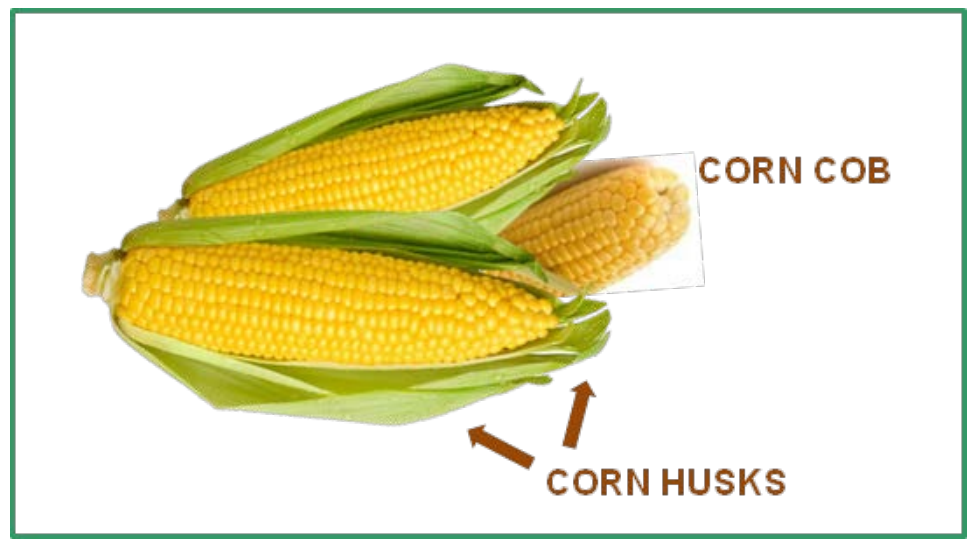

Figure 1. Corn cob and husks.

Flavonoids are secondary plant metabolites that belong to the vast group of phenolic compounds [18]. They play an important role in plant defense mechanisms and are considered to be largely responsible for the health benefits of fruit and vegetable consumption $[19,20]$.

The health-promoting properties of flavonoids are believed to arise primarily from their ability to scavenge free radicals and/or chelate metal ions [21]. In addition to being effective antioxidants, some of these compounds possess chemopreventive properties, which have been related to their capacity to interfere with the carcinogenesis process (initiation, promotion, and progression) [22,23]. Furthermore, mounting evidence from in vitro, in vivo, and epidemiological studies suggests that they may exert anti-inflammatory, anti-allergic, and antibacterial activities [21].

For all the above reasons, the recovery of flavonoids from agro-industrial residues-such as bilberry processing waste [24], olive pomace [25], mandarin peels [26], defatted seeds [27], and citrus by-products [28] — has attracted a great deal of attention in recent years.

In this paper, we investigate the recovery of flavonoids from corn husks by enzyme-assisted extraction. Enzymatic treatments are based on the ability of cell-wall degrading enzymes to hydrolyze the structural components of the plant tissues, thereby facilitating the release of bioactive compounds [29]. We used cellulase as pretreatment agent since cellulose is the major component of corn husks [12]. The main objective of this study was to evaluate the optimum conditions for the recovery of flavonoids and the influence of the main process parameters, alone or in combination, on the extraction yields. To this end, a statistical approach based on Box-Behnken design and response surface methodology was employed.

The results obtained strongly support the use of enzymes as an effective and sustainable means for improving the recovery of flavonoids from corn husks.

\section{Materials and Methods}

\subsection{Chemicals and Plant Material}

Ethanol (CAS 64-17-5), methanol (CAS 67-56-1), aluminum chloride (CAS 7446-70-0), sodium hydroxide (CAS 1310-73-2), sodium nitrite (CAS 7632-00-0), citric acid (CAS 77-92-9), and disodium hydrogen phosphate (CAS 7558-79-4) were purchased from Sinopharm Chemical Reagent Co., Ltd. (Shanghai, China). Rutin [3,3', 4', 5,7-pentahydroxy-flavon3-(o-rhamnosylglucoside)] (CAS 153-18-4) was purchased from Winherb Medical Technology Co., Ltd. (Shanghai, China). Phosphate-citrate buffer 
(PCB) at $0.1 \mathrm{M}$ and $\mathrm{pH} 5$ was prepared by adding proper amounts of disodium hydrogen phosphate and citric acid to double distilled water. All chemicals were reagent grade and used as received.

Cellulase (EC 3.2.1.4), with a claimed activity of 10,000 U/g, was supplied by Macklin Biochemical Co., Ltd. (Shanghai, China). One unit is defined as the amount of enzyme that releases $1 \mu \mathrm{mol}$ of glucose from cellulose in $1 \mathrm{~h}$ at $\mathrm{pH} 5$ and $37^{\circ} \mathrm{C}$.

Corn husks were obtained from fresh corn harvested from fields in the suburbs of Jilin (Changchun, China). The material was dried at $50{ }^{\circ} \mathrm{C}$ in a forced-air dehydrator operating at atmospheric pressure and ground in an electric mill. Then it was sieved to 60 mesh $(250 \mu \mathrm{m})$ and stored in the dark at room temperature until use.

\subsection{Determination of Total Flavonoid Content}

Total flavonoids were determined according to the method proposed by Khorasani et al. [30] with some modifications. Briefly, $1 \mathrm{~mL}$ of properly diluted extract, $4 \mathrm{~mL}$ of $30 \%(v / v)$ methanol, $0.3 \mathrm{~mL}$ of $0.5 \mathrm{M} \mathrm{NaNO}_{2}$ and $0.3 \mathrm{~mL}$ of $0.3 \mathrm{M} \mathrm{AlCl}_{3} \cdot 6 \mathrm{H}_{2} \mathrm{O}$ were added and mixed in a test tube. After incubation at room temperature for $6 \mathrm{~min}, 2 \mathrm{~mL}$ of $1 \mathrm{M} \mathrm{NaOH}$ were added. The mixture was brought to $10 \mathrm{~mL}$ with $30 \%(v / v)$ methanol and the absorbance at $510 \mathrm{~nm}$ was measured with a double-beam spectrophotometer (722N, Jingke Scientific Instrument Co., Ltd., Shanghai, China). The results were expressed as rutin equivalents using a calibration curve obtained with rutin standards $(0-50 \mathrm{mg} / \mathrm{L})$.

\subsection{Enzyme-Assisted Extraction}

One gram of powdered corn husks and $10 \mathrm{~mL}$ of $0.1 \mathrm{M} \mathrm{PCB}$ at $\mathrm{pH} 5.0$ were added and mixed in a screw-capped glass flask. Cellulase was subsequently added in an amount so as to achieve the required enzyme dosage. The resulting solution was incubated at $40{ }^{\circ} \mathrm{C}$ for the desired time. Afterwards, the enzyme was inactivated in boiling water for $5 \mathrm{~min}$. The pretreated material was then subjected to solvent extraction. Batch extraction experiments were performed at $80^{\circ} \mathrm{C}$ for $2 \mathrm{~h}$ using aqueous ethanol as solvent. The liquid-to-solid ratio was varied between 20 and $45 \mathrm{~mL} \mathrm{~g}^{-1}$ and the concentration of ethanol from 40 to $90 \%$ by volume. At the end of the extraction, the flask was rapidly cooled under tap water, the liquid was filtered and assayed for total flavonoids.

The flavonoid extraction yield was calculated as

$$
y=100 \frac{c \times V}{m},
$$

where $c$ is the mass concentration of total flavonoids in the sample, $V$ is the volume of the liquid, and $m$ is the dry weight of corn husks.

\subsection{Experimental Design}

The experiments were carried out according to a Box-Behnken design (BBD) with four factors and three levels. The factors considered were the enzyme dosage (D), the incubation time (T), the liquid-to-solid ratio (R), and the ethanol concentration in the extraction solvent (C). The levels of each factor were selected based on the results of preliminary experiments and on previous studies on similar systems. The actual and coded levels for the four factors are listed in Table 1. Coded levels were determined using the following transformations:

$$
\begin{aligned}
& x_{1}=\frac{D-0.4}{0.1}, \\
& x_{2}=\frac{T-2}{0.5} \\
& x_{3}=\frac{R-35}{5},
\end{aligned}
$$




$$
x_{4}=\frac{C-70}{10}
$$

Table 1. Actual and coded levels of the factors of Box-Behnken design (BBD).

\begin{tabular}{lcccc}
\hline \multicolumn{1}{c}{ Factor } & \multicolumn{3}{c}{ Factor Level } & Unit \\
\hline & $\mathbf{- 1}$ & $\mathbf{0}$ & $\mathbf{+ 1}$ & \\
\hline Enzyme dosage (D) & 0.3 & 0.4 & 0.5 & $\mathrm{~g} / 100 \mathrm{~g}$ \\
Incubation time (T) & 1.5 & 2.0 & 2.5 & $\mathrm{~h}$ \\
Liquid-to-solid ratio (R) & 30 & 35 & 40 & $\mathrm{~mL} \mathrm{~g}^{-1}$ \\
Ethanol concentration (C) & 60 & 70 & 80 & $\% \mathrm{v} / \mathrm{v}$ \\
\hline
\end{tabular}

The flavonoid extraction yield $(y)$ was taken as the response variable. The central point was replicated five times to estimate the pure experimental error and check the reproducibility of the results. Overall, the BBD consisted of $24+5=29$ runs, which were performed in randomized order to minimize the effects of uncontrolled factors (Table 2).

Table 2. Experimental design layout and observed response (y). SO and $\mathrm{RO}$ are the standard and the run order of experiments.

\begin{tabular}{|c|c|c|c|c|c|c|}
\hline \multirow[t]{2}{*}{ SO } & \multirow[t]{2}{*}{ RO } & \multicolumn{4}{|c|}{ Factor Level } & \multirow[t]{2}{*}{$y(g / 100 g)$} \\
\hline & & $x_{1}$ & $x_{2}$ & $x_{3}$ & $x_{4}$ & \\
\hline 1 & 2 & -1 & -1 & 0 & 0 & 1.047 \\
\hline 2 & 3 & 1 & -1 & 0 & 0 & 1.018 \\
\hline 3 & 27 & -1 & 1 & 0 & 0 & 0.890 \\
\hline 4 & 4 & 1 & 1 & 0 & 0 & 1.070 \\
\hline 5 & 9 & 0 & 0 & -1 & -1 & 1.022 \\
\hline 6 & 8 & 0 & 0 & 1 & -1 & 1.037 \\
\hline 7 & 13 & 0 & 0 & -1 & 1 & 1.103 \\
\hline 8 & 25 & 0 & 0 & 1 & 1 & 0.990 \\
\hline 9 & 17 & -1 & 0 & 0 & -1 & 0.991 \\
\hline 10 & 15 & 1 & 0 & 0 & -1 & 1.092 \\
\hline 11 & 26 & -1 & 0 & 0 & 1 & 1.131 \\
\hline 12 & 20 & 1 & 0 & 0 & 1 & 1.215 \\
\hline 13 & 22 & 0 & -1 & -1 & 0 & 1.093 \\
\hline 14 & 10 & 0 & 1 & -1 & 0 & 1.120 \\
\hline 15 & 21 & 0 & -1 & 1 & 0 & 0.992 \\
\hline 16 & 23 & 0 & 1 & 1 & 0 & 1.138 \\
\hline 17 & 14 & -1 & 0 & -1 & 0 & 1.040 \\
\hline 18 & 29 & 1 & 0 & -1 & 0 & 0.898 \\
\hline 19 & 1 & -1 & 0 & 1 & 0 & 0.969 \\
\hline 29 & 12 & 1 & 0 & 1 & 0 & 1.096 \\
\hline 21 & 16 & 0 & -1 & 0 & -1 & 0.966 \\
\hline 22 & 6 & 0 & 1 & 0 & -1 & 1.010 \\
\hline 23 & 7 & 0 & -1 & 0 & 1 & 1.070 \\
\hline 24 & 5 & 0 & 1 & 0 & 1 & 1.136 \\
\hline 25 & 18 & 0 & 0 & 0 & 0 & 1.387 \\
\hline 26 & 19 & 0 & 0 & 0 & 0 & 1.260 \\
\hline 27 & 11 & 0 & 0 & 0 & 0 & 1.334 \\
\hline 28 & 24 & 0 & 0 & 0 & 0 & 1.311 \\
\hline 29 & 28 & 0 & 0 & 0 & 0 & 1.404 \\
\hline
\end{tabular}

The design of experiments and the analysis of results were carried out using the Design-Expert ${ }^{\circledR}$ software (vers. 8.0.6.1, Stat-Ease, Minneapolis, MN, USA). 


\subsection{Heat-Reflux Extraction}

One gram of powdered corn husks and $10 \mathrm{~mL}$ of $0.1 \mathrm{M} \mathrm{PCB}$ at $\mathrm{pH} 5.0$ were mixed and incubated at $40{ }^{\circ} \mathrm{C}$ for $2 \mathrm{~h}$. Afterwards, ethanol was added to obtain a solution at $70 \%$ by volume of this component and the extraction was carried out at $80^{\circ} \mathrm{C}$ for $2 \mathrm{~h}$. Then, the mixture was cooled, filtered and assayed for total flavonoids.

\section{Results}

\subsection{Model Fitting and Analysis of Response Surface}

The experimental data concerning the effects of enzyme dosage (D), incubation time (T), liquid-to-solid ratio (R), and ethanol concentration (C) on the flavonoid extraction yield were fitted to different models (linear, two-factor interaction, quadratic, and cubic). The best results were obtained using the quadratic model

$$
y=a_{0}+\sum_{i} a_{i} x_{i}+\sum_{i} a_{i i} x_{i}^{2}+\sum_{i} \sum_{j} a_{i j} x_{i} x_{j}
$$

where $y$ is the flavonoid extraction yield and $x_{i}$ are the coded independent variables. The model contains 15 unknown parameters: the intercept $\left(a_{0}\right)$, four linear $\left(a_{i}\right)$, four pure quadratic $\left(a_{i i}\right)$, and six interaction $\left(a_{i j}\right)$ coefficients. They were estimated using a stepwise procedure, which consists in a progressive modification of the model by iteratively adding or removing terms in order to keep only the statistically significant ones $(p<0.05)$. Application of this procedure, with the constraint of maintaining the hierarchy of the model, led to the equation

$$
y=a_{0}+a_{1} x_{1}+a_{2} x_{2}+a_{3} x_{3}+a_{4} x_{4}+a_{11} x_{1}^{2}+a_{22} x_{2}^{2}+a_{33} x_{3}^{2}+a_{44} x_{4}^{2}+a_{13} x_{1} x_{3}
$$

The 10 parameters of the reduced model were estimated by the least-square methods. They are listed, together with their standard error (SE), $p$-value and $F$-value in Table 3.

Table 3. Estimated regression coefficients of the reduced model described by Equation (7) with the associated standard errors (SE) and 95\%-confidence intervals (CI).

\begin{tabular}{cccccc}
\hline Coefficient & Term & Value & SE & Low CI & High CI \\
\hline$a_{0}$ & intercept & 1.339 & 0.031 & 1.274 & 1.405 \\
$a_{1}$ & $\mathrm{D}$ & 0.027 & 0.020 & -0.016 & 0.069 \\
$a_{2}$ & $\mathrm{~T}$ & 0.015 & 0.020 & -0.028 & 0.057 \\
$a_{3}$ & $\mathrm{R}$ & -0.005 & 0.020 & -0.047 & 0.038 \\
$a_{4}$ & $\mathrm{C}$ & 0.044 & 0.020 & 0.002 & 0.086 \\
$a_{13}$ & $\mathrm{D} \times \mathrm{R}$ & 0.067 & 0.035 & -0.006 & 0.141 \\
$a_{11}$ & $\mathrm{D} \times \mathrm{D}$ & -0.160 & 0.028 & -0.217 & -0.102 \\
$a_{22}$ & $\mathrm{~T} \times \mathrm{T}$ & -0.148 & 0.028 & -0.206 & -0.090 \\
$a_{33}$ & $\mathrm{R} \times \mathrm{R}$ & -0.155 & 0.028 & -0.212 & -0.097 \\
$a_{44}$ & $\mathrm{C} \times \mathrm{C}$ & -0.121 & 0.028 & -0.179 & -0.064 \\
\hline
\end{tabular}

Overall, the model described reasonably well the experimental data, with an average percent error between experimental and calculated results of about 3.5\%. An examination of the ANOVA results summarized in Table 4 reveals that the model was statistically significant $(p<0.0001)$ while the lack-of-fit was not $(p=0.3567)$. Moreover, the residuals were randomly scattered between -2 and +2 (Figure 2), further supporting the soundness and effectiveness of the model. 
Table 4. ANOVA results for the reduced model described by Equation (7). DF denotes the degrees of freedom, SS the sum of squares, MS the mean squares, $\mathrm{F}$ the $F$-value, and $p$ the $p$-value.

\begin{tabular}{cccccc}
\hline Source & DF & SS & MS & F & $p$ \\
\hline Regression & 9 & 0.410 & $4.60 \times 10^{-2}$ & 9.32 & $<0.0001$ \\
Residual error & 19 & 0.093 & $4.91 \times 10^{-3}$ & & \\
Lack-of-fit & 15 & 0.080 & $5.32 \times 10^{-3}$ & 1.57 & 0.3567 \\
Pure error & 4 & 0.014 & $3.39 \times 10^{-3}$ & & \\
Total & 28 & 0.510 & & & \\
\hline
\end{tabular}

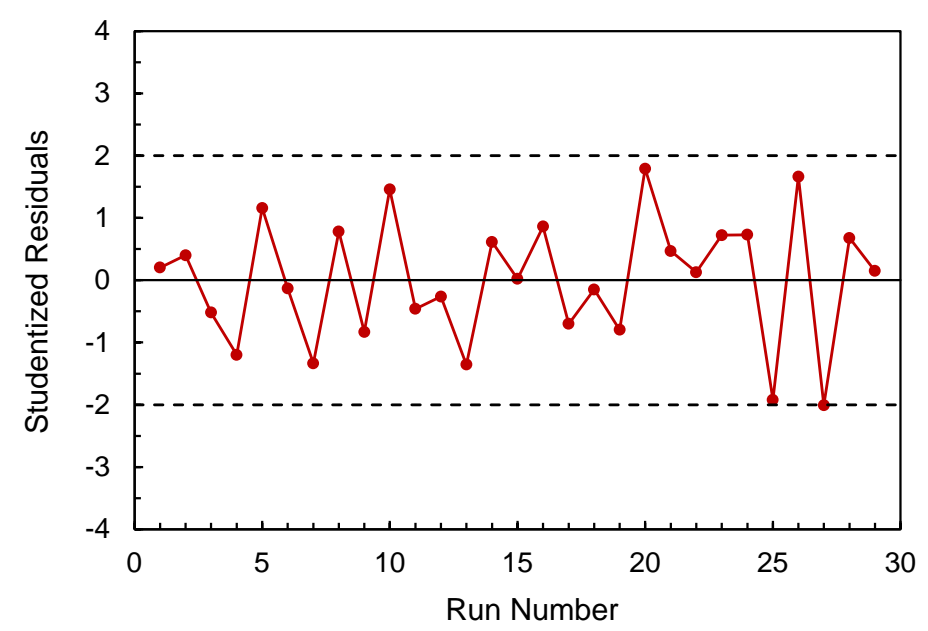

Figure 2. Studentized model residuals as a function of run number.

From the Pareto chart displayed in Figure 3, it can be seen that:

(a) All of the four investigated factors affected the flavonoid extraction yield through both a linear and a quadratic term;

(b) Concerning the linear terms, the $\mathrm{R}$ factor had only a marginal effect on the response variable, while the remaining factors provided a significant and positive contribution, increasing in the order: $\mathrm{T}<\mathrm{D}<\mathrm{C}$;

(c) There was a positive interaction between $\mathrm{D}$ and $\mathrm{R}$, suggesting that the enzyme dosage had a more pronounced effect on flavonoid recovery at higher liquid-to-solid ratios.

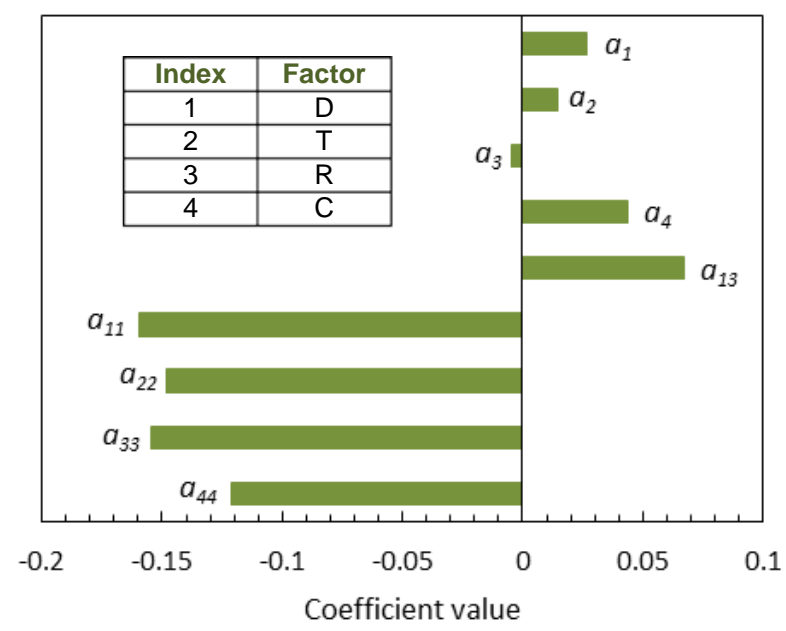

Figure 3. Pareto chart for the model coefficients. 
The effect of the four factors on the extraction yield can be better appreciated by examining the perturbation plots presented in Figure 4. In these plots, each factor was changed over the full range explored $(-1,1)$ while setting the remaining factors to their midpoint values $(0)$. As apparent, the response variable exhibited a non-monotonic variation for all of the factors, with a maximum located around the central point $\left(x_{i}=0\right)$. The relatively steep slope of the two branches of the curves is indicative of a quite high sensitivity of the flavonoid extraction yield to changes in the factor values.
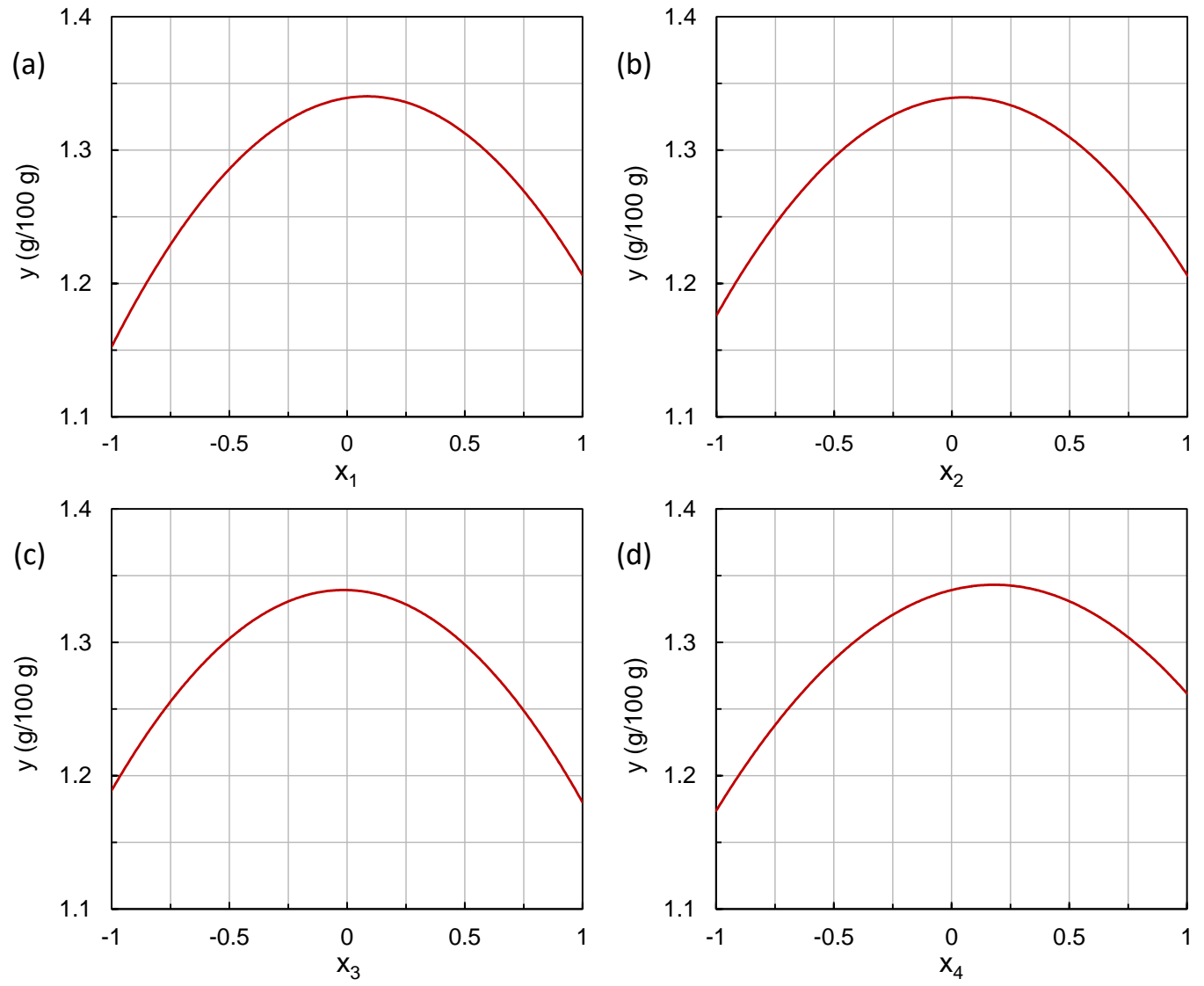

Figure 4. Perturbation plots for the four factors: (a) enzyme dosage; (b) incubation time; (c) liquid-to-solid ratio and (d) ethanol concentration. $y$ is the flavonoid extraction yield and $x_{i}$ is the coded level of factor $i$. Each diagram was plotted by keeping the levels of the other three factors at their central values.

To visualize the combined effects of factors on the recovery of flavonoids, response surface and contour plots were generated from the model equation. The plots shown in Figures 5 and 6 were obtained by holding two of the four factors constant at their midpoint values. The results clearly indicate that the recovery process can be optimized by appropriate selection of extraction conditions. 

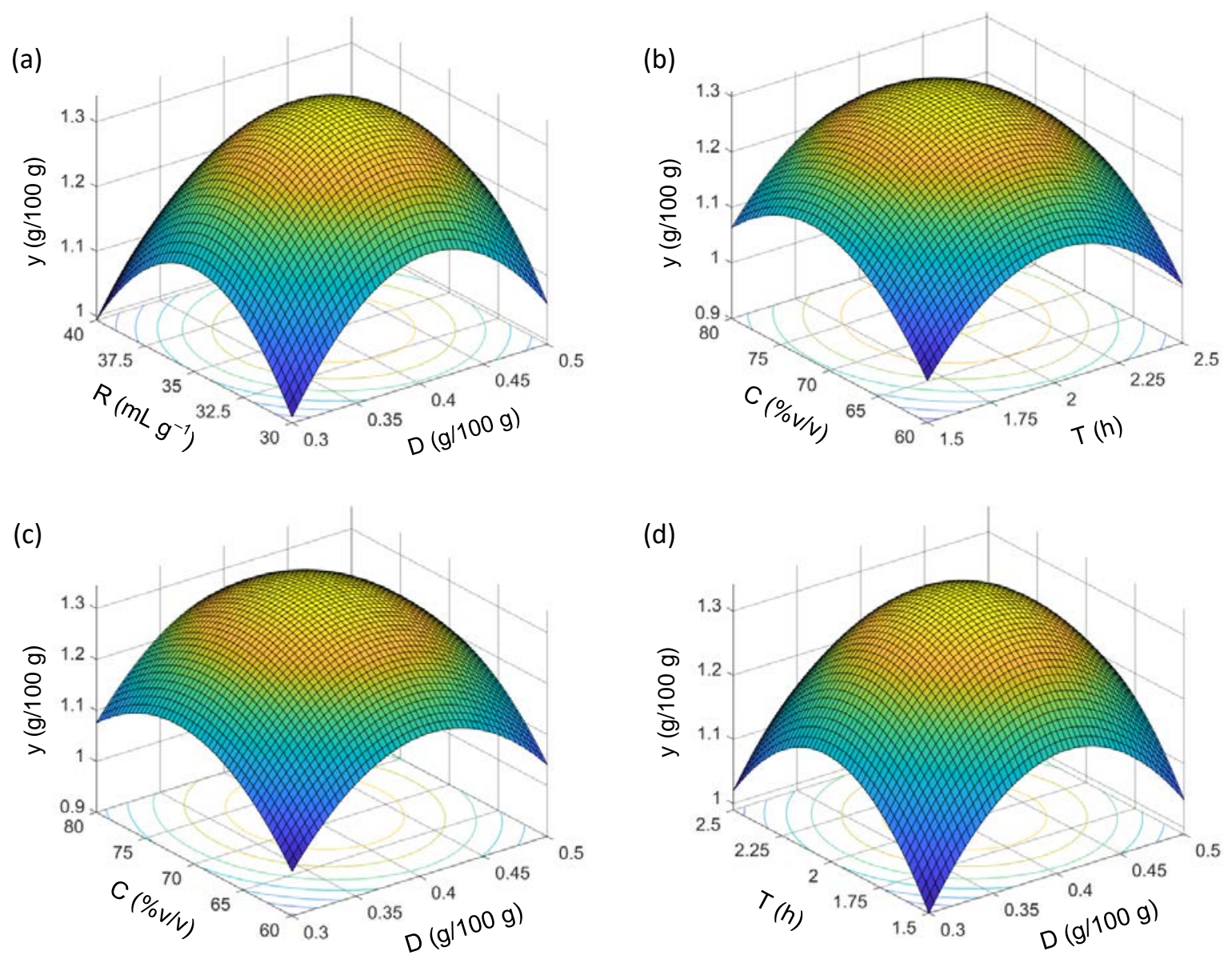

Figure 5. Response surface plots showing the influence of: (a) liquid-to-solid ratio (R) and enzyme dosage (D); (b) ethanol concentration (C) and incubation time (T); (c) ethanol concentration (C) and enzyme dosage (D); and (d) incubation time (T) and enzyme dosage (D) on the flavonoid extraction yield (y). For each plot, the levels of the other factors were held at their central values $(\mathrm{D}=0.4 \mathrm{~g} / 100 \mathrm{~g}$, $\left.\mathrm{T}=2 \mathrm{~h}, \mathrm{R}=35 \mathrm{~mL} \mathrm{~g}^{-1}, \mathrm{C}=70 \% \mathrm{v} / \mathrm{v}\right)$.
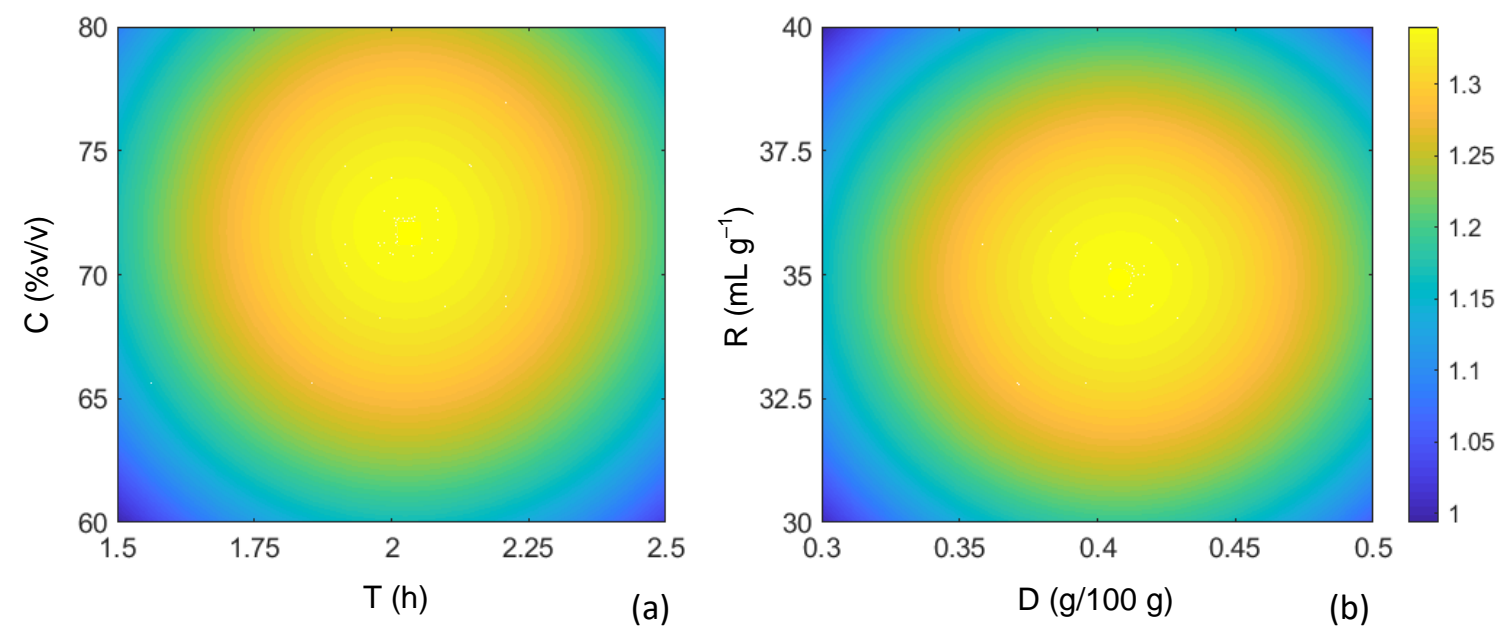

Figure 6. Representative contour plots showing the influence of: (a) ethanol concentration (C) and incubation time (T); and (b) liquid-to-solid ratio (R) and enzyme dosage (D) on the flavonoid extraction yield. For each plot, the levels of the other factors were held at their central values $(\mathrm{D}=0.4 \mathrm{~g} / 100 \mathrm{~g}$, $\left.\mathrm{T}=2 \mathrm{~h}, \mathrm{R}=35 \mathrm{~mL} \mathrm{~g}^{-1}, \mathrm{C}=70 \% \mathrm{v} / \mathrm{v}\right)$. 


\subsection{Optimizazion of Enzyme-Assisted Extraction}

A numerical procedure based on the gradient descent method was used to maximize the response variable. The following results were obtained: $x_{1}=0.08, x_{2}=0.05, x_{3}=0.00, x_{4}=0.18$, with $y=1.345 \mathrm{~g} / 100 \mathrm{~g}$. In terms of actual factors, the maximum was achieved at: $\mathrm{D}=0.41 \mathrm{~g} / 100 \mathrm{~g}, \mathrm{~T}=$ $2.02 \mathrm{~h}, \mathrm{R}=35 \mathrm{~mL} \mathrm{~g}^{-1}, \mathrm{C}=71.8 \%(\mathrm{v} / \mathrm{v})$. The model was validated by performing additional experiments $(n=3)$ under the optimum conditions, which gave: $y_{o b s}=1.308 \pm 0.082 \mathrm{~g} / 100 \mathrm{~g}$. The percentage error between the observed and predicted values was $2.83 \%$.

\subsection{Comparison of Enzyme-Assisted Extraction and Heat-Reflux Extraction}

Heat-reflux extraction experiments performed at $80{ }^{\circ} \mathrm{C}$ for $2 \mathrm{~h}$ with $70 \%$ ethanol as solvent gave an extraction yield of $0.946 \pm 0.103 \mathrm{~g} / 100 \mathrm{~g}$. This value is about $30 \%$ lower than that of $1.308 \pm 0.082 \mathrm{~g} / 100$ g obtained in enzyme-assisted extraction. Therefore, it can be deduced that an enzymatic treatment of corn husks by cellulase has a positive effect on the recovery of flavonoids from the plant material.

\section{Discussion}

This study was undertaken to investigate the recovery of flavonoids from enzymatically treated corn husks. The use of agricultural wastes as sources of value-added products is an important step towards a circular economy, with beneficial effects on the environment and the management of agro-resources. However, contrary to other wastes produced during fruit and vegetable processing — such as bilberry peels [24], olive pomace [25], and citrus byproducts [28] —corn husks have not yet been specifically investigated as a potential source of flavonoids. In particular, the development of an efficient and easily scalable process for the extraction of flavonoids from this material has not been addressed in previous studies. For this reason, the final goal of the present research was to evaluate the optimal extraction conditions of a process based on the use of cellulase and aqueous ethanol for the recovery of flavonoids from corn husks.

Like other phenolic compounds present in vegetables and fruits, flavonoids are usually located within the plant tissues, often in association with cell-wall polysaccharides [31]. The fact that the plant matrix acts as a significant barrier to solvent diffusion and the quite strong interactions between flavonoids and cell-wall components are responsible for the low extraction efficiency of these compounds from the plant sources. As a result, pretreatments of the plant material can be necessary to obtain acceptable extraction yields [32].

Enzyme-assisted extraction processes rely on the capacity of cell-wall degrading enzymes to hydrolyze the structural components of plant tissues, thus facilitating the release of bioactive compounds into the surrounding medium [33,34]. Cellulose, hemicellulose, and pectin are the main structural components of plant cell walls [35]. Cellulose is a linear polymer of $\beta-(1,4)$-D-glucopyranose units. It is organized into microfibrils of amorphous and well-packed hydrogen-bonded crystalline regions. These microfibrils form a fairly rigid polymeric network that is cross-linked by hemicellulose molecules, especially xylans and xyloglucans [36]. The network is embedded in a matrix of hydrated pectic substances and lignin.

Since cellulose is the key structural component of the cell wall, enzymatic pretreatments with cellulases can be expected to have a beneficial effect on the recovery of flavonoids from plant materials [37,38]. This has indeed been observed in several studies on different materials, such as grape pomace [39], plant leaves [40], wood sawdust [41], and fruit residues [42].

In enzyme-assisted extraction processes, cellulase can be used either alone or in combination with other cell-wall degrading enzymes, in single- or multi-stage treatments. In this study, we used cellulase in a single-stage treatment. This was done to develop a simple and easily scalable treatment, and in consideration of the high cellulose content of corn husks, which can reach up to $60 \%$ of the biomass dry weight $[43,44]$. The beneficial effects resulting from the enzymatic treatment of corn husks 
suggest that cellulase is capable of degrading, or at least loosening, the cell wall, favoring the release of flavonoids into the extraction solvent.

The susceptibility of plant cell walls to cellulase attack is known to depend on the relative amounts of amorphous and crystalline cellulose [32,38]. In fact, while the crystalline fraction of cellulose is quite resistant to hydrolytic degradation, amorphous domains are much more reactive and easily hydrolyzable. Accordingly, it is likely that, during the enzymatic treatment of corn husks, the amorphous cellulose is attacked first, followed by the hydrolysis of the crystalline regions.

An important point emerging from the present study is the existence of optimal values for all of the factors investigated. Enzyme dosage and incubation time are two important factors affecting the enzymatic treatment of biomass materials $[29,45,46]$. Enzymes are typically applied at dosages ranging from 0.01 to $10 \%(w / w)$ [38]. In general, the higher the dosage, the greater the extraction yields. However, above a certain value depending on the enzyme used and the characteristics of the biomass, no apparent improvements or a decrease in extraction efficiency are observed. For the enzymatically treated corn husks, the extraction yield was maximum at a cellulase dosage of $0.4 \%(w / w)$. This could be due to the combined effects of enhanced degradation of the cell wall at higher enzyme dosage and non-productive adsorption of cellulase on corn husks.

During the enzymatic degradation of lignocellulosic materials, non-productive adsorption phenomena may result from the interaction of cellulase with lignin on the surface of the plant material $[47,48]$. These phenomena have been widely investigated, especially in relation to the conversion of lignocellulosic biomass into fermentable sugars, but the exact mechanisms involved are far from being fully understood [49-51]. Lignin is a complex, highly branched, aromatic polymer composed of $p$-hydroxyphenyl, guaiacyl, and syringyl units [52]. It has a strong affinity for cellulase, which is bound through hydrophobic and electrostatic interactions [53]. Some evidence also suggests that the irreversibly bound cellulase may lose its folded structure and become denatured [49]. The adsorbed cellulase is unable to carry out the hydrolysis reaction and, since lignin is tightly associated with cellulose, it may cause steric hindrance to the free cellulase molecules. As a result, the amount of enzyme available to attack cellulose is reduced and the hydrolysis rate decreases, negatively affecting the extraction yields.

As for the incubation time, in published studies this quantity was varied from a few tens of minutes to $24 \mathrm{~h}$ or more [38]. The existence of an optimal incubation time can arise from two opposing effects: (a) the increased release of flavonoids resulting from a more extensive disruption of the cell wall and (b) the higher susceptibility of the released flavonoids to degradation. The optimal incubation time will depend on the relative contribution of these effects at the treatment temperature, which influences both of them.

Another important point to emphasize is the dependence of the extraction efficiency on solvent composition. The existence of an optimal composition, close to $70 \%(v / v)$ ethanol for corn husks, has been evidenced in studies on different plant materials such as spent coffee grounds [54], mango by-products [55], brewers' spent grain [56], bilberry residues [57], and artichoke waste [58]. Several factors are likely to be involved, such as solvent affinity for the extracted compounds and various indirect effects of the solvent on the plant tissue. The latter include weakening of the interactions between the bioactive compounds and cell-wall polysaccharides [59], protein denaturation [60], and swelling of the plant tissue [61]. Swelling originates from the adsorption of solvent molecules on specific functional groups of plant tissue components, especially cellulose fibers. This causes an increase in inter-fiber spacing and an expansion of the plant material, which facilitates the penetration of solvent molecules. Water and ethanol, the two components of the solvent used in this study, are known to be effective swelling agents, being characterized by small molar volume, large basicity, and high hydrogen bonding capability $[62,63]$. As a result, it can be speculated that all of the above factors may play a role in determining the observed influence of solvent composition on flavonoid recovery.

A last point to be mentioned here is that the biomass residue obtained from the enzyme-assisted extraction process could be further exploited to recover proteins or other corn husk components and/or 
to produce bioenergy. Likewise, the remaining biomass could be used to create additional value-added products for the food industry. For example, it could serve as a substrate in solid-state fermentation (SSF) to produce chemicals [64,65], crude enzymes [66,67], or other products [68]. In addition to the resulting economic and environmental benefits, this strategy would contribute to providing a transition of the vegetable oil sector to a circular economy through an integrated biorefinery approach.

\section{Conclusions}

Corn husks are an important byproduct of the corn processing industry, but at present they constitute an unused or underutilized resource. In particular, they are a rich source of bioactive flavonoids that could be used in a variety of applications. In this study, we have shown that these compounds can be efficiently recovered by performing an enzymatic treatment of corn husks followed by solvent extraction with aqueous ethanol. Although the mechanisms involved in the overall extraction process are complex and only partly understood, the process can be optimized by carrying out a reasonably small number of experiments on the material of interest. In this regard, the use of a factorial design, such as the BBD, combined with the response surface methodology can be a powerful and effective approach to achieving the above purpose.

Future research should be directed at determining whether and to what extent the recovery of a particular flavonoid present in corn husks could be maximized by proper selection of process conditions. It would also be interesting to apply the life cycle assessment (LCA) methodology to evaluate environmental and economic indicators for assessing the sustainability of the proposed process. Finally, the economic feasibility of the recovery process at the industrial scale should be carefully assessed. In this regard, it is worth noting that several commercial cellulase preparations of relatively low cost are currently available and that ethanol, the extraction solvent, can be easily evaporated and recycled for reuse in the process.

Author Contributions: Methodology, A.Z., R.L., J.B.G.-M., and P.L.; Investigation, J.B.G.-M. and A.D.G.-D.; Writing—original draft preparation, A.Z., R.L., and P.L.; Writing—review and editing, A.Z., R.L., and Á.D.G.-D.

Funding: This research was partially supported by grants from Sapienza University of Rome (Italy). The authors gratefully thank the University of Cartagena (Cartagena, Colombia) and the University Francisco de Paula Santander (Cúcuta, Colombia) for their support.

Conflicts of Interest: The authors declare no conflict of interest.

\section{References}

1. Shiferaw, B.; Prasanna, B.M.; Hellin, J.; Bänziger, M. Crops that feed the world 6: Past successes and future challenges to the role played by maize in global food security. Food Secur. 2011, 3, 307. [CrossRef]

2. Lopez-Martinez, L.X.; Oliart-Ros, R.M.; Valerio-Alfaro, G.; Lee, C.H.; Parkin, K.L.; Garcia, H.S. Antioxidant activity, phenolic compounds and anthocyanins content of eighteen strains of Mexican maize. Food Sci. Technol. 2009, 42, 1187-1192. [CrossRef]

3. Ramos-Escudero, F.; Muñoz, M.A.; Alvarado-Ortíz, C.; Alvarado, A.; Yáñe, J.A. Purple corn (Zea mays L.) phenolic compounds profile and its assessment as an agent against oxidative stress in isolated mouse organs. J. Med. Food 2012, 15, 206-215. [CrossRef] [PubMed]

4. Hasanudin, K.; Hashim, P.; Mustafa, S. Corn silk (Stigma maydis) in healthcare: A phytochemical and pharmacological review. Molecules 2012, 17, 9697-9715. [CrossRef] [PubMed]

5. Liu, J.; Wang, C.; Wang, Z.; Zhang, C.; Lu, S.; Liu, J. The antioxidant and free-radical scavenging activities of extract and fractions from corn silk (Zea mays L.) and related flavone glycosides. Food Chem. 2011, 126, 261-269. [CrossRef]

6. Sarepoua, E.; Tangwongchai, T.; Suriharn, B.; Lertrat, K. Relationships between phytochemicals and antioxidant activity in corn silk. Int. Food Res. J. 2013, 20, 2073-2079.

7. Reddy, N.; Yang, Y. Properties and potential applications of natural cellulose fibers from cornhusks. Green Chem. 2005, 7, 190-195. [CrossRef] 
8. Barl, B.; Biliaderis, C.G.; Murray, E.D.; Macgregor, A.W. Combined chemical and enzymic treatments of corn husk lignocellulosics. J. Sci. Food Agric. 1991, 56, 195-214. [CrossRef]

9. Yoon, K.Y.; Woodams, E.E.; Hang, Y.D. Enzymatic production of pentoses from the hemicellulose fraction of corn residues. LWT Food Sci. Technol. 2006, 39, 388-392. [CrossRef]

10. Hang, Y.D.; Woodams, E.E. Corn husks: A potential substrate for production of citric acid by Aspergillus niger. LWT Food Sci. Technol. 2000, 33, 520-521. [CrossRef]

11. Mahalaxmi, Y.; Sathish, T.; Chaganti, S.R.; Prakasham, R.S. Corn husk as a novel substrate for the production of rifamycin B by isolated Amycolatopsis sp. RSP 3 under SSF. Process. Biochem. 2010, 45, 47-53. [CrossRef]

12. Huda, S.; Yang, Y. Chemically extracted cornhusk fibers as reinforcement in light-weight poly(propylene) composites. Macromol. Mater. Eng. 2008, 293, 235-243. [CrossRef]

13. Xiao, S.; Gao, R.; Gao, L.; Li, J. Poly(vinyl alcohol) films reinforced with nanofibrillated cellulose (NFC) isolated from corn husk by high intensity ultrasonication. Carbohydr. Polym. 2015, 136, 1027-1034. [CrossRef] [PubMed]

14. Li, C.Y.; Kim, H.W.; Won, S.R.; Min, H.K.; Park, K.J.; Park, J.Y.; Ahn, M.S.; Rhee, H.I. Corn husk as a potential source of anthocyanins. J. Agric. Food Chem. 2008, 56, 11413-11416. [CrossRef]

15. Khamphasan, P.; Lomthaisong, K.; Harakotr, B.; Ketthaisong, D.; Scott, M.P.; Lertrat, K.; Suriharn, B. Genotypic variation in anthocyanins, phenolic compounds, and antioxidant activity in cob and husk of purple field corn. Agronomy 2018, 8, 271. [CrossRef]

16. Vijayalaxmi, S.; Jayalakshmi, S.K.; Sreeramulu, K. Polyphenols from different agricultural residues: Extraction, identification and their antioxidant properties. J. Food Sci. Technol. 2015, 52, 2761-2769. [CrossRef]

17. Kupski, L.; Telles, A.C.; Gonçalves, L.M.; Nora, N.S.; Furlong, E.B. Recovery of functional compounds from lignocellulosic material: An innovative enzymatic approach. Food Biosci. 2018, 22, 26-31. [CrossRef]

18. Khalid, M.; Saeed-ur-Rahman; Bilal, M.; Huang, D.-F. Role of flavonoids in plant interactions with the environment and against human pathogens-A review. J. Integr. Agric. 2019, 18, 211-230. [CrossRef]

19. Shashirekha, M.N.; Mallikarjuna, S.E.; Rajarathnam, S. Status of bioactive compounds in foods, with focus on fruits and vegetables. Crit. Rev. Food Sci. Nutr. 2015, 55, 1324-1339. [CrossRef]

20. Leong, H.Y.; Show, P.L.; Lim, M.H.; Ooi, C.W.; Ling, T.C. Natural red pigments from plants and their health benefits: A review. Food Rev. Int. 2018, 34, 463-482. [CrossRef]

21. Mojzer, E.B.; Hrnčič, M.K.; Škerget, M.; Knez, Ž.; Bren, U. Polyphenols: Extraction methods, antioxidative action, bioavailability and anticarcinogenic effects. Molecules 2016, 21, 901. [CrossRef] [PubMed]

22. Rodríguez-García, C.; Sánchez-Quesada, C.; Gaforio, J.J. Dietary flavonoids as cancer chemopreventive agents: An updated review of human studies. Antioxidants 2019, 8, 137. [CrossRef] [PubMed]

23. Hrnčič, M.K.; Španinger, E.; Košir, I.J.; Knez, Ž.; Bren, U. Hop compounds: Extraction techniques, chemical analyses, antioxidative, antimicrobial, and anticarcinogenic effects. Nutrients 2019, 11, 257. [CrossRef] [PubMed]

24. Lavecchia, R.; Medici, F.; Piga, L.; Zuorro, A. Factorial design analysis of the recovery of flavonoids from bilberry fruit by-products. Int. J. Appl. Eng. Res. 2015, 23, 43555-43559.

25. Lavecchia, R.; Zuorro, A. Recovery of flavonoids from three-phase olive pomace by aqueous ethanol extraction. ARPN J. Eng. Appl. Sci. 2016, 11, 13802-13809.

26. Ko, M.-J.; Kwon, H.-L.; Chung, M.-S. Pilot-scale subcritical water extraction of flavonoids from satsuma mandarin (Citrus unshiu Markovich) peel. Innov. Food Sci. Emerg. Technol. 2016, 38, 175-181. [CrossRef]

27. Liau, B.-C.; Ponnusamy, V.K.; Lee, M.-R.; Jong, T.-T.; Chen, J.-H. Development of pressurized hot water extraction for five flavonoid glycosides from defatted Camellia oleifera seeds (byproducts). Ind. Crop. Prod. 2017, 95, 296-304. [CrossRef]

28. Sharma, K.; Mahato, N.; Lee, Y.R. Extraction, characterization and biological activity of citrus flavonoids. Rev. Chem. Eng. 2019, 35, 265-284. [CrossRef]

29. Puri, M.; Sharma, D.; Barrow, C.J. Enzyme-assisted extraction of bioactives from plants. Trends Biotechnol. 2012, 30, 37-44. [CrossRef]

30. Khorasani, E.A.; Mat, T.R.; Mohajer, S.; Banisalam, B. Antioxidant activity and total phenolic and flavonoid content of various solvent extracts from in vivo and in vitro grown Trifolium pratense L. (Red Clover). Biomed. Res. Int. 2015, 2015, 643285. [CrossRef]

31. Agati, G.; Azzarello, E.; Pollastri, S.; Tattini, M. Flavonoids as antioxidants in plants: Location and functional significance. Plant. Sci. 2012, 196, 67-76. [CrossRef] [PubMed] 
32. Zhao, S.; Baik, O.D.; Choi, Y.J.; Kim, S.M. Pretreatments for the efficient extraction of bioactive compounds from plant-based biomaterials. Crit. Rev. Food Sci. Nutr. 2014, 54, 1283-1297. [CrossRef] [PubMed]

33. Baiano, A. Recovery of biomolecules from food wastes-A review. Molecules 2014, 19, 14821-14842. [CrossRef] [PubMed]

34. Gligor, O.; Mocan, A.; Moldovan, C.; Locatelli, M.; Crișan, G.; Ferreira, I.C.F.R. Enzyme-assisted extractions of polyphenols-A comprehensive review. Trends Food Sci. Technol. 2019, 88, 302-315. [CrossRef]

35. Doblin, M.S.; Pettolino, F.; Bacic, A. Plant cell walls: The skeleton of the plant world. Funct. Plant. Biol. 2010, 37, 357-381. [CrossRef]

36. Scheller, H.V.; Ulvskov, P. Hemicelluloses. Annu. Rev. Plant. Biol. 2008, 61, 263-289. [CrossRef]

37. Kuhad, R.C.; Gupta, R.; Singh, A. Microbial cellulases and their industrial applications. Enzyme Res. 2011, 1, 280696. [CrossRef]

38. Lavecchia, R.; Zuorro, A. Cellulase Applications in Pigment and Bioactive Compound Extraction. In New and Future Developments in Microbial Biotechnology and Bioengineering; Gupta, V.K., Ed.; Elsevier: Amsterdam, The Netherlands, 2016; pp. 209-222.

39. Meini, M.-R.; Cabezudo, I.; Boschetti, C.E.; Romanini, D. Recovery of phenolic antioxidants from Syrah grape pomace through the optimization of an enzymatic extraction process. Food Chem. 2019, 283, 257-264. [CrossRef]

40. Chen, S.; Xing, X.H.; Huang, J.J.; Xu, M.S. Enzyme-assisted extraction of flavonoids from Ginkgo biloba leaves: Improvement effect of flavonol transglycosylation catalyzed by Penicillium decumbens cellulase. Enzyme Microb. Technol. 2011, 48, 100-105. [CrossRef]

41. Wang, Y.; Zu, Y.; Long, J.; Fu, Y.; Li, S.; Zhang, D.; Li, J.; Wink, M.; Efferth, T. Enzymatic water extraction of taxifolin from wood sawdust of Larix gmelini (Rupr.) Rupr. and evaluation of its antioxidant activity. Food Chem. 2011, 126, 1178-1185. [CrossRef]

42. Huang, D.; Zhou, X.; Si, J.; Gong, X.; Wang, S. Studies on cellulase-ultrasonic assisted extraction technology for flavonoids from Illicium verum residues. Chem. Cent. J. 2016, 10, 56. [CrossRef] [PubMed]

43. Nema, N.; Alamir, L.; Mohammad, M. Production of cellulase from Bacillus cereus by submerged fermentation using corn husks as substrates. Int. Food Res. J. 2015, 22, 1831-1836.

44. Yilmaz, N.D.; Sulak, M.; Yilmaz, K.; Kalin, F. Physical and chemical properties of water-retted fibers extracted from different locations in corn husks. J. Nat. Fibers 2016, 13, 397-409. [CrossRef]

45. Zuorro, A.; Lavecchia, R.; Medici, F.; Piga, L. Use of cell wall degrading enzymes for the production of high-quality functional products from tomato processing waste. Chem. Eng. Trans. 2014, 38, 355-360.

46. Zuorro, A.; Maffei, G.; Lavecchia, R. Optimization of enzyme-assisted lipid extraction from Nannochloropsis microalgae. J. Taiwan Inst. Chem. Eng. 2016, 67, 106-114. [CrossRef]

47. Donohoe, B.S.; Resch, M.G. Mechanisms employed by cellulase systems to gain access through the complex architecture of lignocellulosic substrates. Curr. Opin. Chem. Biol. 2015, 29, 100-107. [CrossRef]

48. Lu, X.; Zheng, X.; Li, X.; Zhao, J. Adsorption and mechanism of cellulase enzymes onto lignin isolated from corn stover pretreated with liquid hot water. Biotechnol. Biofuels 2016, 9, 118. [CrossRef]

49. Siqueira, G.; Arantes, V.; Saddler, J.N.; Ferraz, A.; Milagres, A.M.F. Limitation of cellulose accessibility and unproductive binding of cellulases by pretreated sugarcane bagasse lignin. Biotechnol. Biofuels 2017, 10, 176. [CrossRef]

50. Vermaas, J.V.; Petridis, L.; Qi, X.; Schulz, R.; Lindner, B.; Smith, J.C. Mechanism of lignin inhibition of enzymatic biomass deconstruction. Biotechnol. Biofuels 2015, 8, 217. [CrossRef]

51. Rahikainen, J.; Mikander, S.; Marjamaa, K.; Tamminen, T.; Lappas, A.; Viikari, L.; Kruus, K. Inhibition of enzymatic hydrolysis by residual lignins from softwood-study of enzyme binding and inactivation on lignin-rich surface. Biotechnol. Bioeng. 2011, 108, 2823-2834. [CrossRef]

52. Dos Santos, A.C.; Ximenes, E.; Kim, Y.; Ladisch, M.R. Lignin-enzyme interactions in the hydrolysis of lignocellulosic biomass. Trends Biotechnol. 2019, 37, 518-531. [CrossRef] [PubMed]

53. Rahikainen, J.L.; Evans, J.D.; Mikander, S.; Kalliola, A.; Puranen, T.; Tamminen, T.; Marjamaa, K.; Kruus, K. Cellulase-lignin interactions-The role of carbohydrate-binding module and $\mathrm{pH}$ in non-productive binding. Enzyme Microb. Technol. 2013, 53, 315-321. [CrossRef] [PubMed]

54. Zuorro, A.; Lavecchia, R. Polyphenols and energy recovery from spent coffee grounds. Chem. Eng. Trans. 2011, 25, 285-290. 
55. Dorta, E.; Lobo, M.G.; Gonzalez, M. Reutilization of mango byproducts: Study of the effect of extraction solvent and temperature on their antioxidant properties. J. Food Sci. 2012, 77, C80-C88. [CrossRef] [PubMed]

56. Zuorro, A.; Iannone, A.; Lavecchia, R. Water-organic solvent extraction of phenolic antioxidants from brewers' spent grain. Processes 2019, 7, 126. [CrossRef]

57. Fidaleo, M.; Lavecchia, R.; Zuorro, A. Extraction of bioactive polyphenols with high antioxidant activity from bilberry (Vaccinium myrtillus L.) processing waste. Orient. J. Chem. 2016, 32, 759-767. [CrossRef]

58. Zuorro, A.; Maffei, G.; Lavecchia, R. Reuse potential of artichoke (Cynara scolimus L.) waste for the recovery of phenolic compounds and bioenergy. J. Clean. Prod. 2016, 111, 279-284. [CrossRef]

59. Sun, R.C.; Sun, X.F.; Wang, S.Q.; Zhu, W.; Wang, X.Y. Ester and ether linkages between hydroxycinnamic acids and lignin from wheat, rice rye, and barley straws, maize stems, and fast-growing poplar wood. Ind. Crop. Prod. 2002, 15, 179-188. [CrossRef]

60. Damoderan, S. Protein: Danaturation. In Handbook of Food Science, Technology and Engineering; Hui, Y.K., Ed.; CRC Press: Boca Raton, FL, USA, 2005.

61. Obataya, E.; Gril, J. Swelling of acetylated wood I: Swelling in organic liquids. J. Wood Sci. 2005, 51, $124-129$. [CrossRef]

62. El Seoud, O.A. Understanding solvation. Pure Appl. Chem. 2009, 81, 697-707. [CrossRef]

63. Fidale, L.C.; Ruiz, N.; Heinze, T.; El Seoud, O.A. Cellulose swelling by aprotic and protic solvents: What are the similarities and differences? Macromol. Chem. Phys. 2008, 209, 1240-1254. [CrossRef]

64. Kachrimanidou, V.; Kopsahelis, N.; Chatzifragkou, A.; Papanikolaou, S.; Yanniotis, S.; Kookos, I.; Koutinas, A.A. Utilisation of by-products from sunflower-based biodiesel production processes for the production of fermentation feedstock. Waste Biomass Valoriz. 2013, 4, 529-537. [CrossRef]

65. Papadaki, A.; Androutsopoulos, N.; Patsalou, M.; Koutinas, M.; Kopsahelis, N.; de Castro, A.M.; Papanikolaou, S.; Koutinas, A.A. Biotechnological production of fumaric acid: The effect of morphology of Rhizopus arrhizus NRRL 2582. Fermentation 2017, 3, 33. [CrossRef]

66. Kachrimanidou, V.; Kopsahelis, N.; Vlysidis, A.; Papanikolaou, S.; Kookos, I.K.; Monje Martínez, B.; Escrig Rondán, M.C.; Koutinas, A.A. Downstream separation of poly(hydroxyalkanoates) using crude enzyme consortia produced via solid state fermentation integrated in a biorefinery concept. Food Bioprod. Process. 2016, 100, 323-334. [CrossRef]

67. Papadaki, A.; Kachrimanidou, V.; Papanikolaou, S.; Philippoussis, A.; Diamantopoulou, P. Upgrading grape pomace through Pleurotus spp. cultivation for the production of enzymes and fruiting bodies. Microorganisms 2019, 7, 207. [CrossRef] [PubMed]

68. Papadaki, A.; Kopsahelis, N.; Mallouchos, A.; Mandala, I.; Koutinas, A.A. Bioprocess development for the production of novel oleogels from soybean and microbial oils. Food Res. Int. 2019, 126, 108684. [CrossRef] 